\title{
DAMPAK INFORMASI SOSIAL DAN LINGKUNGAN TERHADAP KEPUTUSAN MANAJER
}

\author{
Deva Eristiani \\ Program Studi Akuntansi STIE Bank BPD Jateng \\ devaeristiani23@gmail.com \\ Grace Tianna Solovida \\ Program Studi Akuntansi STIE Bank BPD Jateng \\ Tianna3186@gmail.com
}

\begin{abstract}
The increasing concern and focus on the social and environmental impacts lead many companies to consider making a social and environmental report. The report was intended to the external parties; however, it may benefit the internal parties especially for the manager in conducting the project. This research aimed to obtain empirical evidence on the influence of the social and environmental information to the manager decision. The population of this research was the students from the private university in Semarang who have enrolled in Akuntansi Manajemen and Sistem Pengendalian Manajemen (the management accounting and management control system), and the sample was 98 students. The research employed One Way ANOVA using SPSS. The result of this study indicated that social and environmental information significantly influenced the manager decision.
\end{abstract}

Keywords : Social and environmental accounting, Stakeholder theory, Project evaluation.

\section{PENDAHULUAN}

Pengambilan keputusan oleh manajer dalam teori ekonomi diasumsikan untuk memaksimalkan keuntungan (Harrison dan Harrell, 1993). Oleh karena itu, informasi akuntansi yang menunjukkan kinerja ekonomi adalah sumber utama informasi dalam pengambilan keputusan evaluasi proyek (Harrison dan Harrell, 1993; Rutledge dan Karim, 1999; Booth dan Schulz, 2004; Chong dan Suryawati, 2010).

Meningkatnya perhatian dan fokus atas dampak sosial dan lingkungan bisnis, telah menyebabkan sejumlah perusahaan secara aktif memperhitungkan dan mengelola pengungkapan pelaporan sosial dan lingkungan (Adams dan Frost, 2008). Kesadaran tentang pentingnya pelaporan Corporate Social Responsibility (CSR) semakin marak dikarenakan masyarakat semakin peduli akan produk-produk yang ramah lingkungan (Susanto, 2007). Pengungkapan tersebut bertujuan untuk menjalin hubungan komunikasi yang baik dan efektif antara perusahaan dengan publik dan stakeholder lainnya tentang bagaimana perusahaan telah 
mengintegrasikan Corporate Social Responsibility (CSR) dan lingkungan sosial dalam setiap kegiataan operasinya (Darwin, 2007). Sebuah perusahaan akuntansi terbesar di dunia, KPMG, telah merilis survei mengenai pelaporan pertangunggjawaban perusahan 2017. Survei tersebut menunjukkan ada peningkatan dalam pelaporan pertanggungjawaban menjadi $93 \%$ perusahaan yang terdiri dari 250 perusahaan terbesar di dunia. Dengan sampel yang lebih besar yakni 100 perusahaan terbesar dari setiap 49 negara di dunia, survei ini juga menunjukkan bahwa 75\% dari 4900 perusahaan juga melaksanakan praktik ini. Hal ini menunjukkan adanya keseragaman pada perusahaan untuk mempraktikkan pelaporan pertanggungjawaban. Peningkatan ini disebabkan adanya peraturan baru yang diterapkan di beberapa negara seperti Meksiko, Selandia baru, dan Taiwan.

Menurut KPMG (2015), munculnya kesadaran bagi perusahaan untuk melakukan pelaporan tentang informasi sosial dan lingkungan dapat disebabkan oleh dua faktor yaitu pertama pemegang saham yang memerlukan informasi pertanggungjawaban untuk memahami risiko dan peluang perusahan, kedua adanya persyaratan atau aturan yang dikeluarkan oleh pemerintah agar perusahaan melakukan pelaporan pertanggungjawaban.

Berita mengenai pelaporan sosial dan lingkungan yang dikutip dari detiknews (24/2/2018) yaitu mengenai pentingnya pelaporan sosial dan lingkungan sebagai mengungkapkan secara transparan dalam pelaksanaan tanggung jawab sosial dan lingkungan, ditandai adanya penyerahan Sustainability Report Award (SRA) 2017 kepada 10 winner atau pemenang di Hotel Lorin, Colomadu, Karanganyar. Sementara, isu mengenai pelaporan sosial dan lingkungan sebenarnya sudah ada sejak 2015 mengutip dari salah satu situs berita kompas.com (18/12/2015) yang diungkapkan oleh Sarwono, ketua tim Sustainability Reporting Award (SRA) 2015, bahwa laporan sosial dan lingkungan merupakan kewajiban bagi perusahaan di Indonesia karena laporan sosial dan lingkungan bermanfaat untuk menghindari investasi dari risiko sosial dan risiko lingkungan. Menurut Sarwono, manfaat laporan sosial dan lingkungan adalah untuk memberikan keyakinan kepada investor dan kreditor tentang risiko sosial dan risiko lingkungan.

Vardon et. Al (2018) menemukan bahwa penggunaan informasi ekonomi 
dan informasi lingkungan sangat berpengaruh dalam pengambilan keputusan bagi pemerintah dan bisnis. Kaya (2016) mengemukakan bahwa informasi sosial dan lingkungan perusahaan diperlukan bagi pemegang saham untuk memahami risko dan peluang perusahaan. Madein (2015), mengemukakan bahwa informasi sosial dan lingkungan sangat berpengaruh pada pengambilan keputusan manajer. Penelitian yang berfokus pada penggunaan informasi akuntansi sosial dan lingkungan bagi pihak eksternal meliputi Guidry dan Patten (2010), Rikhardsson dan Holm (2008), Murrayet al. (2006), Hassel et al. (2005), AlTuwaijri et al. (2004), Milne dan Patten (2002), Chan dan Milne (1999), TeohdanShiu (1990), Anderson dan Frankle (1980), Hendricks (1976), dan Belkaoui (1976). Penelitian-penelitian sebelumnya tentang informasi sosial dan lingkungan lebih berpedoman pada Agency Theory (Jensen dan Meckling 1976). Inti dari teori-teori tentang pentingnya pihak luar, yaitu para stakeholder dalam mempengaruhi keputusan perusahan dalam pelaporan informasi lingkungan. Penggunaan manajer dalam unit analisis dalam penelitian ini dapat mempertimbangkan seberapa pentingnya peran manajer dalam mengambil keputusan dalam perusahaan terutama dalam evaluasi proyek.

Penelitan Harrioson dan Harell (1993) mengandalkan teori keagenan dalam keputusan evaluasi proyek. Sedangkan menurut Hill dan Jones (1992) berargumen bahwa teori keagenan memiliki kelemahan karena hubungan antara pemangku kepentingan tidak dijelaskan mengenai hubungan kontrak implisit atau eksplisit yang terjadi di perusahaan. Oleh karena itu kelemahan teori keagenan dapat diimbangi dengan teori stakeholder yang memiliki cakupan yang lebih luas. Keragaman teori stakeholder dalam kelompok pemilik saham dalam perusahaan yaitu menjelaskan hubungan kontrak implisit dan eksplisit dengan semua pemangku kepentingan perusahan (Freeman 1984; Freeman et al 2010).

Penelitian ini dilatarbelakangi oleh penggunaan informasi sosial dan lingkungan yang sejauh ini lebih diperuntukkan bagi pihak eksternal seperti yang sudah di jelaskan pada survei KPMG dan detiknews bahwa pelaporan sosial dan lingkungan sangat penting untuk pelestarian lingkungan. Selain itu informasi sosial dan lingkungan dapat bermanfaat dalam menghindari dari risiko sosial dan 
lingkungan. Oleh karena itu, informasi sosial dan lingkungan dapat berdampak dalam pengambilan keputusan manajer menentukan perusahaan untuk berinvestasi. Selain itu, penggunaan informasi sosial dan lingkungan masih jarang digunakan dalam pengambilan keputusan oleh para manajer terlebih dalam pengambilan keputusan evaluasi sebuah proyek. Penggunaan informasi sosial dan lingkungan masih dipandang sebagai tanggung jawab perusahaan untuk melaporkan pertanggungjawaban sosial dan lingkungan kepada masyarakat agar memperoleh dukungan dari masyarakat atas kepeduliannya terhadap lingkungan. Sehingga pihak internal (manajer) belum memanfaatkan informasi sosial dan lingkungan sebagai bagian dalam pengambilan keputusan.

Penelitian ini mengacu pada penelitian Madein (2015), serta penelitian yang menunjukkan hasil dari pengaruh informasi sosial dan lingkungan terhadap keputusan manajer di Indonesia belum banyak diteliti. Penelitian ini akan membuktikan bahwa informasi sosial dan lingkungan dapat berpengaruh dalam pengambilan keputusan manajer.

\section{Perumusan Masalah}

Dari latar belakang permasalahan yang sudah diungkapkan sebelumnya, permasalahan yang akan diambil dalam penelitian adalah :

1. Apakah informasi sosial dan lingkungan berpengaruh terhadap keputusan manajer?

2. Apakah informasi ekonomi berpengaruh terhadap keputusan manajer?

\section{Tujuan Penelitian}

Sesuai dengan perumusan masalah yang telah dijabarkan diatas, maka dapat diketahui tujuan dari penelitian ini sebagai berikut :

1. Memberikan bukti secara empiris pengaruh informasi sosial dan lingkungan terhadap keputusan manajer.

2. Memberikan bukti secara empiris pengaruh informasi ekonomi terhadap keputusan manajer.

\section{Manfaat Penelitian}

Penelitian ini memiliki kontribusi teoritis dan praktis. Kontribusi yang diharapkan dari penelitian ini adalah liti, menambah pengetahuan, wawasan, dan gambaran yang lebih jelas mengenai bagaimana pihak internal perusahaan, yaitu manajer sebagai praktisi internal perusahaan, menanggapi informasi sosial dan lingkungan dan diharapkan dapat memberikan informasi yang bermanfaat kepada para praktisi, dapat menjadi referensi, dan pembanding 
untuk penelitian selanjutnya mengenai penggunaan informasi sosial dan lingkungan pada pengambilan keputusan manajer.

\section{TINJAUAN PUSTAKA DAN PENGEMBANGAN HIPOTESIS}

\section{Teori Stakeholder}

Pelopor pendekatan stakeholder dalam perusahaan adalah Robert E. Freeman yang dituangkan dalam sebuah buku berjudul manajemen strategis: suatu pendekatan stakeholder, yang diterbitkan pada tahun 1984 (Donaldson dan Preston 1995; Jones 1995). Inti dari teori ini adalah kebutuhan perusahaan mengelola hubungan dengan kelompokkelompok pemangku kepentingan: kelompok atau individu yang dapat mempengaruhi tercapainya tujuan perusahaan (Freeman 1984). Menurut pendapat Jones dan Wicks (1999) bagian penting dalam teori stakeholder adalah :

1. Perusahaan memiliki hubungan dengan banyak kelompokkelompok stakeholder;

2. Teori yang berhubungan dengan proses dan hasil bagi perusahaan dan pemangku kepentingan;

3. Kepentingan semua pemangku kepentingan memiliki nilai intrinsik dan tidak ada yang saling mendominasi (Clarkson 1995; Donaldson dan Preston 1995); dan

4. Teori ini berfokus pada pengambilan keputusan manajer ( Donaldson dan Preston 1995).

Teori stakeholder diurai menjadi tiga jenis menurut Donaldson dan Preston (1995) yaitu deskriptif, instrumental, dan normatif. Teori stakeholder deskripsif atau yang dikenal dengan teori empiris menggambarkan karakteristik dan perilaku perusahaan secara spesifik (Donaldson dan Preston 1995). Teori stakeholder instrumental atau yang biasa disebut teori stakeholder strategis (Wall dan Grelling 2011), mengasumsikan bahwa permasalahan utama antara perusahaan dan pemangku kepentingan adalah kepercayaan dan kerja sama (Jones 1955). Tipe teori yang terakhir yaitu teori stakeholder normatif, teori ini digunakan untuk menafsirkan fungsi perusahaan, identifikasi filosofi dalam operasi dan manajemen perusahaan (Donaldson dan Preston 1995).

Jones dan Wicks (1999) mengusulkan teori konvergen stakeholder, teori ini adalah berisi kompenen normatif dan kompenen instrumental. Henriques dan sadorsky (1999) mengklasifikasikan perusahaan menjadi empat yaitu reaktif, defensif, akomodatif, dan proaktif. Perusahaan 
reaktif adalah perusahaan yang bagian manajemen puncak tidak melaporkan laporan lingkungan karena menganggap manajemen lingkungan tidak perlu. Perusahaan defensif adalah perusahaan yang sedikit peduli pelaporan lingkungan sehingga hanya menangani isu-isu lingkungan bila diperlukan. Perusahaan akomodatif adalah perusahaan yang melihat pelaporan lingkungan sebagai fungsi berharga dan memberikan beberapa karyawan mengenai pelatihan lingkungan. Perusahaan proaktif adalah perusahaan yang sangat menekankan pelaporan lingkungan baik internal maupun eksternal, serta mendukung karyawan dan pihak terkait untuk terlibat dalam isu-isu lingkungan.

Teori stakeholder memperkirakan manajemen untuk memperhatikan ekspektasi dari stakeholder yang berkuasa, yaitu stakeholder yang memiliki kuasa mengendalikan sumberdaya yang dibutuhkan oleh perusahaan (Deegan, 2000). Ketika stakeholder mengendalikan sumber-sumber penting dalam ekonomi bagi perusahaan, maka perusahaan akan bereaksi dengan caracara yang dapat memuaskan keinginan stakeholder (Ullman,1985).

\section{Informasi Sosial}

Pelaporan sosial merupakan komponen dari laporan pertanggungjawaban sosial yang menyediakan informasi mengenai hasil hubunganinteraksi dan dampak-dampak yang muncul akibat kegiatan organisasi/perusahaan dengan masyarakat.

Belkaoui (1989) menemukan hasil (1) pengungkapan sosial mempunyai hubungan yang positif dengan kinerja sosial perusahaan yang berarti bahwa perusahaan yang melakukan kegiatan sosial akan mengungkapkannya dalam laporan sosial, (2) ada hubungan positif antara pengungkapan sosial dengan visibilitas politis, dimana perusahaan besar yang cenderung diawasi, sehingga perusahaa besar akan lebih banyak mengungkapkan informasi sosial dibandingkan perusahaan kecil, (3) ada hubungan negatif antara pengungkapan sosial dengan tingkat financial leverage, dengan demikian berarti semakin tinggi rasio utang/modal semakin rendah pengungkapan sosialnya karena semakin tinggi tingkat leverage maka semakin besar kemungkinan perusahaan akan melanggar perjanjian kredit. Sehingga perusahaan harus menyajikan laba yang lebih tinggi pada saat ini dibandingkan 
laba di masa depan. Oleh karena itu, perusahaan dapat menyajikan laba yang lebih tinggi, maka perusahaan harus mengurangi biaya-biaya (termasuk biaya-biaya untuk mengungkapkan informasi sosial).

Pengungkapan informasi sosial oleh perusahan seringkali disebut sebagai tanggung jawab sosial perusahan atau Corporate Social Responsibility (CSR) adalah cara perusahaan mengelola akitivitas bisnis secara sebagian maupun secara keseluruhan yang memiliki dampak positif bagi perusahaan dan lingkungan sekitar perusahan (Tiarasandy 2018). Berdasarkan undang-undang tentang perseroan terbatas no. 40 tahun 2007 pasal 1 ayat 3 menyatakan bahwa tanggung jawab sosial dan lingkungan adalah komitmen perusahaan dalam berperan serta membangun perekonomian berkelanjutan guna meningkatkan kualitas kehidupan dan lingkungan yang bermanfaat, baik bagi perusahaan sendiri, lingkungan sekitar, maupun masyarakat umum.

Menurut Darwin (2004), Corporate Social Responsibility (CSR) adalah suatu mekanisme yang dilakukan oleh perusahaan secara sukarela untuk menginterasikan perhatian terhadap lingkungan dan sosial dalam operasinya, yang mana melebihi tanggung jawab organisasi di bidang hukum. Definisi sistematis informasi sosial yaitu pengembangan informasi yang bermanfaat dalam mengevaluasi kinerja sosial perusahaan dan mengkomunikasikan informasi sosial perusahaan kepada kelompok sosial yang tertarik, baik di dalam maupun di luar perusahaan (Anggraini 2006).

Menurut Daniri (2008), pengungkapan tanggung jawab sosial adalah tangung jawab moral perusahaan dalam strategic stakeholders perusahaan, terlebih lagi dalam komunitas dan masyarakat di sekitar wilayah operasi perusahaan. Selain itu menurut Hackston dan milne (1996), informasi sosial adalah proses pengkomunikasian dampak sosial dan lingkungan dari kegiatan ekonomi perusahaan terhadap kelompok yang berkepentingan khusus dan terhadap masyarakat.

Perusahaan dituntut untuk memberikan informasi yang transparan, perusahaan yang akuntabel serta tata kelola perusahaan yang baik (good corporate governance), oleh karena itu perusahaan dipaksa untuk memberikan informasi mengenai aktivitas sosial dalam sustainability report atau laporan keberlanjutan perusahaan (Anggraini 
2006). Tujuan dari pengungkapan tanggung jawab sosial menurut Gray, Owen, dan Maunders (1988) yaitu untuk meningkatkan image perusahaan, untuk meningkatkan akuntabilitas suatu organisasi, dengan asusmi adanya kontrak sosial antara perusahaan dengan masyarakat, dan untuk memberikan informasi kepada investor.

\section{Informasi Lingkungan}

Informasi lingkungan adalah informasi tentang kegiatan atau program perusahaan terkait lingkungan atau dampak kegiatan perusahaan terhadap lingkungan di sekitarnya. Informasi tersebut dapat diungkapkan dalam jenis media yang berbeda, seperti website perusahaan, surat kabar, majalah, dan melalui laporan tahunan perusahaan.

Adanya isu-isu tentang sosial dan lingkungan mendorong akuntansi untuk berkembang lebih dari aspek ekonomi. Perkembangan tersebut, mengakibatkan akuntansi lingkungan yang terus menekan dampak lingkungan, hinggga meluas ke aspek sosial (Schaltegger et al 2006). Akuntansi yang berdampak pada sosial dan lingkungan sering disebut dengan istilah lain seperti : akuntansi manajemen lingkungan yang berfokus pada aspek lingkungan termasuk ecocontrol (Henri dan Journeault 2010); lingkungan biaya (Atkinson et al 2011); akuntansi sosial yang berfokus pada aspek sosial (Gray 2002). Akuntansi sosial dan lingkungan (Mathews 1997); akuntansi tangung jawab sosial perusahaan yang menggabungkan antara aspek sosial dan lingkungan (Schaltegger et al 2006).

Menurut Al-Tuwaijir et al (2004), informasi lingkungan berhubungan positif dan signifikan dengan kinerja lingkungan. Oleh karena itu, perusahaan menganggap bahwa kinerja lingkungan yang baik akan mengurangi risiko dan biaya lingkungan di masa depan, maka pengungkapan informasi lingkungan akan diterima sebagai infromasi yang baik oleh investor. Pengungkapan informasi lingkungan merupakan salah satu usaha perusahaan untuk meningkatkan pengetahuan stakeholder karena dengan perusahaan mengungkapkan informasi lingkungan sebagai hasil tekanan stakeholder, maka tingkat dan kualitas informasi lingkungan yang dipublikasikan lebih dipengaruhi oleh kepentingan manajemen (Hadjoh 2013). Menurut Ghozali dan Chariri (2007), pengungkapan informasi lingkungan merupakan usaha perusahaan mengirimkan pesan kepada stakeholder tentang hal-hal yang dilakukan perusahaan untuk kepentingan 
sosial dan lingkungan. Informasiinformasi yang tersedia dalam pengungkapan lingkungan yaitu diskusi regulasi dan persyaratan dampak lingkungan, kebijakan lingkungan atau kepedulian terhadap lingkungan, konservasi sumber daya alam, usaha dalam melakukan daur ulang limbah, perhargaan atas kepedulian terhadap lingkungan, pengeluaran yang dilakukan perusahaan berkaitan dengan penanganan lingkungan, dan segala kasus dalam aspek hukum yang berkaitan dengan dampak lingkungan yang disebabkan perusahaan (Wiseman 1982). Menurut Belkaoui (2000) pengungkapan informasi lingkungan berisi tentang seberapa besar perusahaan memberikan kontribusi terhadap kualitas hidup masyarakat dan lingkungan sekitar masyarakat.

Menurut Ahmad dan Sulaiman (2004), pengungkapan informasi lingkungan dalam laporan tahunan perusahaan merupakan suatu yang masih bersifat sukarela, sehingga ada tidaknya pengungkapan ini dalam laporan tahunan perusahaan tergantung pada kebijakan dan pengawasan dari masingmasing perusahaan. Walaupun pengungkapan lingkungan di laporan tahunan perusahaan masih bersifat sukarela, namun saat ini pelaporan pengungkapan tanggung jawab sosial dan lingkungan telah diwajibkan bagi perseroan terbatas untuk melaporkan informasi sosial dan lingkungan dalam laporan tahunan di Indonesia. Hal ini dijelaskan dalam UU No. 40 tahun 2007 tentang Perseroan Terbatas Pasal 66 dan 74 , pada pasal 66 ayat 2 bagian c tertulis bahwa laporan tahunan diwajibkan melaporkan Pelaksaan Tanggung Jawab Sosial dan Lingkungan, untuk pasal 74 ayat 1 tertulis bahwa perseroan yang menjalankan kegiatan usahanya di bidang dan/atau yang berkaitan dengan sumber daya alam wajib melaksanakan Tanggung Jawab Sosial dan Lingkungan.

Menurut Pfleiger (2005), melaporkan informasi lingkungan dapat memberikan dampak positif bagi perusahan seperti meningkatnya daya tarik investor terhadap keuntungan perusahaan akibat pengelolaan lingkungan hidup yang bertanggung jawab berdasarkan penilaian masyarakat.

\section{Akuntansi dan Manajemen Proyek}

Proyek dapat diartikan sebagai sebuah usaha atau kegiatan sementara yang dilakukan bertujuan membuat unit produk, layanan, atau hasil (Larson dan Gray 2011). Sebagai usaha sementara, manajemen proyek memilki siklus 
kehidupan yang meliputi perencanaan, pelaksanaan, evaluasi, dan penutupan (Boddy 2002).

Menurut Mulyadi (2008), Akuntansi Manajemen memiliki dua arti yaitu akuntansi manajemen sebagai informasi dan akuntansi manajemen sebagai suatu sistem pengolahan informasi keuangan.

Salah satu sumber utama informasi manajer untuk mengambil keputusan adalah akuntansi (Hall 2010). Akuntansi sebagai sumber informasi dapat membantu manajer untuk mengembangkan pengetahuan tetang lingkungan kerja (Hall 2010). Oleh karena itu, selain menunjukkan masalah ekonomi akuntansi juga harus mampu menunjukkan masalah yang terkait dengan aspek-aspek sosial dan lingkungan sebagai aspek dalam pengambilan keputusan seorang manajer

\section{Keputusan Manajer}

Keputusan merupakan suatu tindakan yang dilakukan dalam memilih dari beberapa opsi yang ada, dengan adanya tindakan ini akan menghasikan konsekuensi yang berhubungan dengan hasil dari tindakan tersebut. Pengambilan keputusan seringkali diibaratkan dengan proses berpikir, mengatur, dan menyelesaikan masalah. Pengambilan keputusan dalam perusahaan seringkali diartikan sebagai proses penentuan berbagai pilihan alternatif tindakan yang dapat mempengaruhi masa depan (Kahneman dan Tversky 1986).

Pengambilan keputusan dapat dibagi menjadi berbagai macam definisi. Menurut Syamsi (2000), pengambilan keputusan adalah suatu kegiatan atau tindakan yang dilakukan oleh manajer atau pimpinan perusahaan untuk memecahkan masalah yang dihadapi perusahaannya dengan memilih satu dari berbagai alternatif-alternatif yang memungkinkan. Sedangkan menurut Arfan dan Muhammad (2005), pengambilan keputusan adalah proses memilih diantara alternatif-alternatif tindakan yang akan mempengaruhi masa depan. Dapat disimpulkan dari kedua pernyataan tersebut bahwa pengambilan keputusan adalah proses dari pemilihan satu alternatif-alternatif dari suatu tindakan. Oleh karena itu, pengambilan keputusan merupakan proses dimana seseorang manajer atau pemimpin perusahaan yang harus memilih satu alternatif yang dapat berguna dalam memecahkan masalah yang memiliki efek bagi masa depan perusahaan tersebut. 
Hipotesis

Hipotesis merupakan jawaban sementara terhadap masalah dalam penelitian ini yang masih bersifat prasangka karena masih harus dibuktikan kebenarannya. Hipotesis yang digunakan pada penelitian ini adalah sebagai berikut :

Teori stakeholder merupakan teori manajemen dan etika organisasi (Philips et al 2003). Oleh karena itu, teori stakeholder memberikan penjelasan bahwa keputusan manajemen didasarkan oleh prinsip-prinsip manajemen organisasi dan nilai-nilai perusahaan, terlebih lagi dalam pengambilan keputusan yang melibatkan pemangku kepentingan. Teori konvergen pemangku kepentingan merupakan prinsip-prinsip manajemen organisasi dan nilai-nilai perusahaan.

Salah satu faktor yang mempengaruhi penggunaan informasi untuk mengembangkan pengetahuan tentang lingkungan kerja adalah kerangka informasi (Hall 2010). Baik maupun buruknya sebuah informasi sosial dan lingkungan dapat memberikan informasi tentang efek eksternal dan sosial bagi keputusan manajer, sehingga manajer dapat menentukan keputusan yang lebih baik (Grit 2004).
Informasi akuntansi adalah informasi yang sangat penting yang diperlukan oleh manajer dalam mengelola sebuah proyek perusahaan. Infomasi sosial dan lingkungan dapat memberikan informasi yang berguna bagi manajer dalam penyesuaian strategi manajer (Henri dan Journeault 2010). Ketika informasi sosial dan lingkungan menyajikan informasi dapat membuat manajer yakin untuk melanjutkan proyek tersebut. Namun ketika informasi sosial dan lingkungan menyajikan informasi yang buruk dapat membuat manajer mengubah keputusan mereka bahkan manajer juga dapat membatalkan proyek tersebut.

Berdasarkan pendekatan instrumental teori stakeholder, manajer mencoba untuk meningkatkan kinerja ekonomi dengan mempertimbangkan informasi sosial dan lingkungan karena kinerja pertanggungjawaban sosial dapat meningkatkan kinerja ekonomi perusahaan melalui pengembangan sumber daya tak berwujud perusahan seperti inovasi, reputasi, budaya, dan SDM (Surroca et al 2010). Kinerja sosial dan lingkungan yang baik dapat berdampak mengurangi risiko jangka panjang dari kekurangan sumber daya, fluktuasi energi, dan meningkatkan citra 
dan kinerja ekonomi perusahaan (Henri

dan Journeault 2010).

Menurut teori konvergen

stakeholder, informasi sosial dan lingkungan digunakan oleh manajer untuk menjaga hubungan antara perusahaan (manajer) dengan pihak sosial dan lingkungan. Menurut Freeman dan Philips (2012), tugas manajer adalah menjaga para pemangku kepentingan agar selalu mendukung perusahaan melalui menyeimbangkan kepentingan perusahan dan pemangku kepentingan. Manajer dapat meningkatkan kontraktor dan kinerja ekonomi dengan mempertimbangkan informasi mengenai tindakan manajer dan isu-isu lingkungan (Henri dan Journeault 2010). Selain itu, manajer dapat mempertimbangkan informasi sosial dan lingkungan dari nilai intrinsik para pemangku kepentingan dan manfaat masing-masing pemangku kepentingan (Donaldson dan Preston 1995). Oleh karena itu, hipotesis dinyatakan sebagai berikut:

H0: manajer yang diberikan informasi ekonomi yang buruk dan diberikan informasi sosial dan lingkungan yang baik lebih memungkinkan untuk melanjutkan proyek daripada manajer yang hanya diberikan informasi ekonomi yang buruk.
H1: manajer yang diberikan informasi ekonomi yang baik dan diberikan informasi sosial dan lingkungan yang buruk lebih memungkinkan untuk tidak melanjutkan proyek daripada manajer yang hanya diberikan informasi ekonomi yang baik.

\section{METODE PENELITIAN}

\section{Populasi dan Sampel}

Pemilihan data merupakan bagian dari proses pengujian data yang berkaitan dengan jumlah dan jenis data yang akan diteliti. Pemilihan populasi dan sampel pada penelitian ini menggunakan metode purposive sampling. Metode purposive sampling adalah salah satu teknik pengambilan sampel non-probability sampling/non random sample yang dilakukan dengan menentukan kriteria yang sesuai dengan tujuan dari peneltian diharapkan responden dapat menjawab permasalahan penelitian. Populasi yang digunakan dalam penelitian ini adalah mahasiswa jurusan akuntansi yang telah mengambilan mata kuliah Akuntansi Manajemen dan Sistem Pengendalian Manajemen di universitas swasta di Semarang. Penelitian ini menggunakan mahasiswa sebagai subyek karena dalam penelitian Liyanarachchi dan Milne (2005) mengemukakan bahwa tidak 
adanya perbedaan keputusan investasi antara praktisi akuntansi dan mahasiswa dalam masalah informasi sosial dan lingkungan.

\section{Metode Pengumpulan Data}

Menggunaan data primer, Indriantoro dan Supomo (2002) data primer adalah sumber data penelitian yang diperoleh secara langsung dari sumber asli atau responden. Data primer akan dikumpulkan oleh peneliti untuk menjawab pertanyaan penelitian. Penelitian ini menggunakan kuesioner sebagai data primer. Kuesioner merupakan salah satu alat teknik dalam pengumpulan data yang dilakukan dengan cara memberikan seperangkat pertanyaan atau pernyataan tertulis kepada responden untuk dijawabnya.

\section{Metode Analisis Data}

Setelah data penelitian terkumpul, langkah selanjutnnya adalah menganalisis data. Tujuannya adalah untuk menyusun dan menginterpretasikan data (kuantitatif) yang sudah diperoleh (Bambang Prasetyo, 2005).

Metode analisis yang digunakan dalam penelitian ini menggunakan metode analisis kuantitatif dengan alat analisis statistika yang didukung dengan software aplikasi SPSS.

\section{Statistik Deskriptif}

Menurut Sugiyono (2015), statistik deskriptif adalah statistik yang digunakan untuk menganalisis data dengan cara mendeskripsikan atau menggambarkan data yang telah terkumpul sebagaimana adanya tanpa bermaksud membuat kesimpulan yang berlaku untuk umum atau generalisasi. Termasuk dalam statistik deskriptif antara lain adalah penyajian data melalui tabel, grafik, diagram lingkaran, perhitungan nilai rata-rata (mean), nilai maksimum, nilai minimum, dan standar deviasi.

\section{Uji Instrumen}

Pengujian validitas dan reliabilitas dilakukan dalam menguji kualitas data untuk data primer

\section{Uji Validitas}

Pengujian ini digunakan untuk menguji valid atau tidak suatu kuesioner, kuesioner akan valid apabila pertanyaan pada kuesioner mampu mengungkapkan sesuatu yang akan diukur dari kuesioner tersebut. Dengan nilai correlated Item untuk menguji validitasnya. Total Correlation dengan kriteria sebagai berikut: Jika nilai $\mathrm{r}$ hitung lebih besar dari $r$ table dan nilainya positif, maka butir pertanyaan atau indikator tersebut dikatakan"valid" (Ghozali, 2006). Masing-masing konstruk yang lebih dari 
0,5 merupakan diatas ambang batas konvergen yang dapat diterima (Fornell dan Lacker, 1981). Kriteria pengujian validitas penelitian: apabila nilai $r$ mendekati 0 , maka kuesioner tersebut kurang valid, apabila nilai r mendekati 1 atau -1, maka kuesioner tersebut sangat valid, apabila nilai $\mathrm{r}$ ditengah, kurang lebih antara 1 dan -1, maka kuesioner tersebut sedang.

\section{Uji Reliabilitas}

Uji reliabilitas adalah untuk mengukur suatu kuesioner yang merupakan indikator dari variabel atau konstruk (Ghozali, 2006). Suatu kuesioner dikatakan reliabel atau handal jika jawaban seseorang terhadap pernyataan tersebut konsisten atau stabil dari waktu ke waktu.

Untuk mengukur reliabilitas digunakan uji statistik Cronbach Alfa $(\alpha) . \quad$ Suatu variabel dikatakan Reliabel jika memberikan nilai Cronbach's Alfa $>0,60$, sedangkan jika sebaliknya data tersebut dikatakan tidak Reliabel (Ghozali, 2011).

\section{Uji Kualitas Data}

\section{Uji Normalitas}

Uji normalitas bertujuan untuk menguji apakah sebelum sampel data digunakan dalam uji-t, sampel harus memenuhi asumsi distribusi normal (memiliki sebaran normal). Sehingga perlu dilakukan pengujian mengenai asumsi kenormalan. Statistik uji untuk kenormalan data yang paling sering digunakan adalah Kolmogorov-Smirnov Test atau yang sering juga disebut Lilliefors Test. Menurut Ghozali (2011), data kuesioner dianggap berdistribusi normal jika nilai pada kolom most extreme-absolut pada tabel hasil perhitungan Kolmogorov-Smirnov dengan menggunakan software SPSS mempunyai nilai lebih besar daripada nilai tingkat signifikansi 0,05 .

\section{Uji Homogenitas}

Uji Homogenitas Adalah pengujian yang dilakukan untuk mengetahui sama tidaknya varian-varian dua buah distribusi atau lebih. Homogenitas adalah ukuran yang menggambarkan bahwa data sampel penelitian mempunyai varian residual yang relatif sama atau tidak berbeda jauh. Uji homogenitas dimaksudkan untuk memperlihatkan bahwa dua atau lebih kelompok data sampel berasal dari populasi yang memiliki varian yang sama. Uji homogenitas perlu dilakukan untuk mengetahui apakah data dalam variabel bersifat homogen atau tidak dalam suatu populasi yang memiliki varian yang sama. Dengan demikian, data yang homogen tersebut dapat digunakan untuk proses analisis data 
pada tahap selanjutnya. Uji homogenitas data sampel dapat dilaksanakan memakai teknik uji Levene's test.

\section{Pengujian Hipotesis}

\section{Uji One Way ANOVA}

Uji One way Anova menunjukkan perbedaan mean atau ratarata kelompok yang berupa nilai atau angka. Dari perbedaan rata-rata setiap kelompok atau sel akan diketahui kelompok mana yang memiliki kecederungan untuk melanjutkan proyek. Taraf signifikansi yang digunakan pada penelitian ini sebesar $5 \%(0,05)$. Hal tersebut menunjukkan bahwa tingkat kesalahan dalam penelitian ini sebesar 5\% dan tingkat kepercayaan sebesar 95\%. Untuk melihat signifikansi hasil pengujian penelitian ini dapat dilihat dari Pvalue hasil pengolahan data. Jika Pvalue signifikansi $\leq 0,05$ atau jika $F$ hitung lebih besar dari F tabel, Maka hipotesis yang diajukan dapat diterima. Sedangkan jika Pvalue signifikansi $>0,05$ atau jika Fhitung lebih kecil dari Ftabel, maka hipotesis ditolak (Ghozali, 2011).

\section{HASIL DAN PEMBAHASAN Gambaran Umum Objek Penelitian}

Penelitian ini mengambil data dengan melakukan eksperimen di universitas swasta di Semarang.
Partisipan dari penelitian ini adalah mahasiwa S1 akuntansi yang telah memasuki semester kelima terhitung sejak pertama mahasiwa tersebut masuk kuliah. Penelitian ini dilaksanakan selama kurang lebih satu bulan yang dimulai pada 10 Desember 2018 sampai dengan 4 Januari 2019 di fakultas ekonomi Unissula, fakultas ekonomi dan bisnis Udinus, fakultas ekonomika dan bisnis Untag, fakultas ekonomika dan bisnis Unisbank, dan fakultas ekonomi STIE Bank BPD Jateng.

Partisipan yang mengikuti penelitian ini berjumlah 110 partisipan, kuesioner yang disebar berjumlah 110 buah dan jumlah kuesioner yang kembali adalah sebanyak 100 kuesioner. Dari 100 data yang kembali sebanyak 2 data yang tidak lolos dalam pengujian manipulasi yang dilakukan setelah eksperimen sehingga data tersebut tidak dapat diolah lebih lanjut. Responden dinyatakan tidak lolos pengujian manipulasi ketika tidak menjawab dengan benar pernyataan pada post manipulation check pada kuesioner berkaitan dengan pemahaman responden mengenai proyek tersebut. Dengan demikian data yang dapat diolah lebih lanjut dalam penelitian ini sejumlah 98 data partisipan. Selanjutnya data yang lolos dalam pengujian manipulasi dibagi menjadi 4 kelompok 
eksperimen secara acak. Kemudian data tersebut dianalisis dengan uji normalitas dan menghasilkan seluruh data yang berjumlah 98 berdistribusi normal.

Responden pada penelitian ini berjumlah 98 reponden dengan jumlah responden yang berjenis kelamin lakilaki 36 orang sedangkan responden yang berjenis kelamin perempuan sejumlah 62 orang. Usia dari reponden bermacammacam, responden yang berusia 20 tahun berjumlah 23 orang, reponden yang beusia 21 tahun berjumlah 59, dan reponden yang berusia 22 berjumlah 16 orang. Selain itu, jumlah reponden yang sudah berkerja yaitu 74 orang dan jumlah responden yang belum bekerja yaitu 24 orang. Sedangkan untuk responden yang sudah pernah mengikuti organisasi sebanyak 39 dan repsonden yang belum pernah mengikuti organisasi sebanyak 59 orang. Berikut tabel yang menjelaskan data responden dari eksperimen penelitian ini.

Tabel 1

Data Responden Eksperimen

\begin{tabular}{llcc}
\hline \multicolumn{2}{c}{ Keterangan } & Jumlah & Presentase \\
\hline Jenis Kelamin & Laki-laki & 36 & $36,7 \%$ \\
\hline \multirow{2}{*}{ Usia } & Perempuan & 62 & $63,3 \%$ \\
\hline \multirow{2}{*}{ Bekerja } & 20 & 23 & $23,5 \%$ \\
\hline \multirow{2}{*}{ Sudah Pernah } & 59 & $60,2 \%$ \\
\hline Berorganisasi & Sudah Pernah & 59 & $16,3 \%$ \\
\hline & Belum pernah & 39 & $75,5 \%$ \\
\hline
\end{tabular}

\section{Sumber: data primer diolah tahun 2019}

\section{Pengujian dan Pembahasan Hipotesis}

Hipotesis memprediksi bahwa manajer yang diberikan informasi ekonomi yang buruk dan diberikan informasi sosial dan lingkungan yang baik lebih memungkinkan untuk melanjutkan proyek daripada manajer yang hanya diberikan informasi ekonomi yang buruk. Pengujian hipotesis 1 dilakukan dengan dua tahapan yaitu pertama membandingkan nilai mean antar kelompok, dan kedua menguji 
signifikansi perbedaan antar kelompok dengan ANOVA. Uji One way ANOVA dilakukan dengan ketentuan sebagai berikut.

Tabel 2

Statistik Deskriptif Hipotesis

\begin{tabular}{|c|c|c|}
\hline \multirow{2}{*}{ Informasi Sosial Dan Lingkungan } & \multicolumn{2}{|c|}{ Informasi Ekonomi } \\
\hline & Baik & Buruk \\
\hline \multirow[t]{8}{*}{ Menerima } & $\mathrm{n} / \mathrm{a}$ & Grup D \\
\hline & & $\mathrm{N}: 25$ \\
\hline & & $\mathrm{Y}: 3,77$ \\
\hline & & SD : 0,98 \\
\hline & Grup B & $\mathrm{n} / \mathrm{a}$ \\
\hline & $\mathrm{N}: 24$ & \\
\hline & $\mathrm{Y}: 4,10$ & \\
\hline & SD : 0,77 & \\
\hline \multirow{2}{*}{ Informasi Sosial Dan Lingkungan } & \multicolumn{2}{|c|}{ Informasi Ekonomi } \\
\hline & Baik & Buruk \\
\hline \multirow[t]{4}{*}{ Tidak Menerima } & Grup A & Grup C \\
\hline & $\mathrm{N}: 25$ & $\mathrm{~N}: 24$ \\
\hline & $\mathrm{Y}: 3,87$ & $\mathrm{Y}: 4,08$ \\
\hline & $\mathrm{SD}: 1,04$ & $\mathrm{SD}: 0,86$ \\
\hline
\end{tabular}

Sumber: data primer diolah tahun 2019

Tabel 3

Hasil Pengujian ANOVA

ANOVA

\begin{tabular}{|c|c|c|c|c|c|}
\hline & $\begin{array}{l}\text { Sum of } \\
\text { Squares }\end{array}$ & Df & $\begin{array}{l}\text { Mean } \\
\text { Square }\end{array}$ & $\mathrm{F}$ & Sig. \\
\hline $\begin{array}{l}\text { Between } \\
\text { Groups }\end{array}$ & 306,095 & 1 & 306,095 & 6,446 & ,013 \\
\hline $\begin{array}{l}\text { Within } \\
\text { Groups }\end{array}$ & 4558,935 & 96 & 47,489 & & \\
\hline Total & 4865,031 & 97 & & & \\
\hline
\end{tabular}

\section{Sumber: data primer diolah tahun 2019}


Tabel 4

Hasil Pengujian Analisis Kontras

Contrast Tests

\begin{tabular}{lrrrrrr}
\hline \multicolumn{1}{c}{ Contrast } & $\begin{array}{c}\text { Value } \\
\text { of } \\
\text { Contrast }\end{array}$ & $\begin{array}{c}\text { Std. } \\
\text { Error }\end{array}$ & T & Df & $\begin{array}{c}\text { Sig. (2- } \\
\text { tailed) }\end{array}$ \\
\hline Assume equal variances & 4,67 & 1,838 & 2,539 & 96 &, 013 \\
\hline $\begin{array}{l}\text { Does not assume equal } \\
\text { variances }\end{array}$ & 4,67 & 1,949 & 2,394 & 21,981 &, 026 \\
\hline
\end{tabular}

\section{Sumber: data primer diolah tahun 2019}

Berdasarkan tabel 4 dalam menguji hipotesis menunjukkan bahwa ada perbedaan yang signifikan diantara semua kelompok dalam penelitian ini. Hal ini dibuktikan dengan tingkat signifikansi yang kurang dari 0,05 yaitu $0,013<0,05$. Pengujian hipotesis selanjutnya menggunakan perbandingan antar kelompok-kelompok dengan menggunakan analisis kontras.

Hipotesis (H0) memprediksi bahwa manajer yang diberikan informasi ekonomi yang buruk dan diberikan informasi sosial dan lingkungan yang baik memungkinkan untuk melanjutkan proyek daripada manajer yang hanya diberikan informasi ekonomi yang buruk. Tabel 4 menunjukkan nilai kontras dari setiap kelompok $(4,67)$ dan menegaskan perbedaan yang signifikan secara statistik (nilai p 0,013<0,05) dan (nilai p 0,026 < 0,05). Hal ini berarti tidak ada perbedaan rata-rata antara informasi sosial dan lingkungan dari keputusan manajer di setiap kelompok.

Berdasarkan tabel 2 menunjukkan jumlah responden di setiap kelompok adalah 26 responden untuk grup A, 25 responden untuk grup B, 23 responden untuk grup $\mathrm{C}$, dan 24 responden untuk grup D. Responden pada grup A merupakan responden yang hanya diberikan informasi ekonomi yang baik, informasi ini diberikan pada keputusan untuk menghentikan atau melanjutkan yang harus diambil manajer. Pada grup A sebagai kelompok kontrol rata-rata informasi ekonomi jawaban respoden sebesar 1,75 memiliki kecenderungan untuk memilih pada skala 2 yaitu semakin yakin melanjutkan proyek.

Sedangkan untuk grup B dari 25 responden, kelompok ini menerima informasi ekonomi yang baik dan informasi sosial dan lingkungan yang buruk tabel 2 menunjukkan rata-rata 
untuk informasi ekonomi sebesar 1,92, cenderung memilih skala 2 yaitu semakin yakin melanjutkan proyek. Sedangkan rata-rata untuk informasi sosial dan lingkungan sebesar 4,10, nilai ini memilki kecenderungan pada skala 4 yaitu setuju untuk melanjutkan proyek.

Pada kelompok kontrol kedua dengan 23 responden yaitu grup $\mathrm{C}$ yang hanya menerima informasi ekonomi yang buruk. Tabel 2 menunjukan dari 23 repsonden grup C sebanyak 18 responden memilih untuk melajutkan proyek dengan nilai rata-rata dari informasi ekonomi sebesar 1,78, cenderung memilih skala 2 yaitu melanjutkan proyek.

Beradsarkan tabel 2, kelompok eksperimen yang kedua yaitu grup D memiliki 24 responden yang menerima informasi ekonomi yang buruk dan informasi sosial dan lingkungan yang baik. Grup D menunjukkan rata-rata informasi ekonomi sebesar 1,78 yang memiliki kecenderungan pada skala 2 yaitu melanjutkan proyek. Sedangkan untuk rata-rata informasi sosial dan lingkungan sebesar 3,77 yang juga memilki kecenderungan pada skala 4 yaitu setuju untuk melanjutkan proyek.

Berdasarkan analisis di atas terbukti bahwa variabel informasi sosial dan lingkungan berpengaruh terhadap keputusan manajer terbukti dengan ratarata responden memilih untuk melajutkan proyek. Hal ini dikarenakan tidak inginnya manajer merusak reputasinya sebagai manajer investasi apabila tidak melanjutkan proyek. Variabel ini didukung dengan analisis respon reponden tabel 4.2 yang diketahui rata-rata nilai indeks dari variabel informasi sosial dan lingkungan sebesar 77,6 yang berarti variabel informasi sosial dan lingkungan memiliki respon yang tinggi. Selain itu indikator nilai indeks yang paling tinggi terdapat pada indikator ISL8 sebesar 81, indikator ini menjelaskan tentang pengolahan limbah sebelum dibuang sehingga menurunkan pencemaran lingkungan yang disebabkan oleh limbah perusahaan. Indikator nilai indeks terendah ISL6 sebesar 74,2 yaitu indikator ISL6 ini berkaitan dengan kerjasama perusahan dengan para pemangku kepentingan untuk mengatasi masalah lingkungan. Hal ini menunjukkan bahwa indikator pengelolaan limbah perusahaan mempengaruhi keputusan manajer untuk melanjutkan proyek terbukti dengan indikator pengolahan limbah menjadi indikator yang memiliki rata-rata indeks nilai tertinggi dibandingkan dengan indikator lainnya. 
Selanjutnya dari analisis jawaban responden tabel 4.3 dapat diketahui bahwa responden paling banyak menyatakan setuju pada variabel informasi sosial dan lingkungan terbukti dengan jumlah skor 4 , berdasarkan skala likert yang menunjukkan setuju. sehingga dapat diartikan bahwa variabel informasi sosial dan lingkungan dapat berpengaruh terhadap pengambilan keputusan manajer. Sehingga jika dikaitkan dengan analisis dari pengujian hipotesis yang mana nilai kontras dari setiap kelompok juga sebesar 4,67, maka hal ini menunjukkan bahwa informasi sosial dan lingkungan berpengaruh terhadap keputusan manajer.

Menurut Boner dan Sprinkle (2002) menyatakan bahwa individu akan bersikap netral terhadap risiko atau memilih proyek yang lebih berisiko untuk mendapatkan return yang diekspektasikan yang lebih besar, atau sebaliknya individu akan menjadi risk averse dan memilih proyek yang lebih aman dengan retrun yang lebih kecil. Penelitian ini membuktikan bahwa adanya hubungan yang signifikan antara informasi sosial dan lingkungan terhadap keputusan manajer.

Seperti yang sudah dijelaskan oleh Madein (2015) bahwa informasi sosial dan lingkungan yang penting dalam pemanfaatan informasi oleh manajer khususnya dalam pengambilan keputusan. Selain itu dalam teori stakeholder menurut Madein (2015) menyatakan bahwa ada hubungan yang signifikan dengan berbagai pemangku kepentingan (pihak eksternal) antara keputusan manajer.

Menurut Vardon (2018),menunjukkan adanya hubungan yang signifikan anatara informasi lingkungan dan informasi ekonomi dengan pengambilan keputusan manajer. Sedangkan dalam penelitian Dari (2016) menyatakan ada hubungan yang signifikan antara informasi sosial dan lingkungan dengan keputusan manajer. Penelitian Burhany (2014) menyatakan bahwa adanya hubungan positif antara akuntansi lingkungan dan kinerja lingkungan terhadap informasi lingkungan.

\section{KESIMPULAN DAN SARAN}

Berdasarkan analisis dan pembahasan yang telah dilakukan, maka dapat disimpulkan bahwa :

1. Informasi sosial dan lingkungan adalah informasi yang penting untuk perusahaan terlebih lagi bagi manajer (pihak internal) terlihat dari pemanfaatan informasi sosial dan lingkungan dalam 
pengambilan keputusan evaluasi investasi proyek,

2. Teori stakeholder juga menunjukkan adanya keharusan pengelolaan hubungan dengan berbagai pemangku kepentingan sehingga dapat memprediksi keputusan manajer dalam keputusan yang melibatkan banyak pemangku kepentingan

\section{Keterbatasan dan Saran}

\section{Keterbatasan}

Terdapat beberapa keterbatasan pada penelitian ini dan diharapkan dapat diperbaiki pada penelitian-penelitian selanjutnya.

1. Keterbatasan yang pertama pada penelitian ini ada di bagian penggunaan informasi sosial dan lingkungan yang bersifat kualitatif yang memiliki kelemahan dari segi kemampuan jika diperbandingkan sehingga mengurangi nilai informasi sosial dan lingkungan tersebut. Teoh dan Shiu (1990) menunjukkan bahwa informasi sosial yang bersifat kuantitatif lebih dipertimbangkan oleh investor dalam pengambilan keputusan investasinya.

2. Keterbatasan kedua dalam penelitian ini yaitu terkait dengan penggunaan mahasiswa sebagai penyulih (surrogate) manajer. Meskipun telah dilakukan seleksi dengan memilih mahasiswa akuntansi yang telah

mengambil matakuliah Akuntansi Manajemen dan Sistem Pengendalian Manajemen, namun pemahaman mereka terhadap kasus tidak diuji langsung. Responden juga tidak diuji tingkat kekhawatirannya terhadap sosial dan lingkungan.

3. Selanjutnya, keterbatasan penelitian ini juga terkait dengan tidak dipertimbangkannya pengaruh sumber informasi yang mungkin menjadi hal yang dipertimbangkan oleh manajer sebagaimana yang sudah dijelaskan oleh Fisher (1996).

\section{Saran}

Dalam pengembangan penelitian ini, keterbatasan tersebut dapat menjadi topik penelitian yang menarik untuk dikaji dan diperbaiki. Pengembangan yang bertujuan untuk memperluas generalisasi juga dapat dilakukan dengan menggunakan kasus yang lain dalam melakukan eksperimen. Pengembangan penelitian ini juga dapat dilakukan dengan menguji berbagai variabel lain yang dapat memperngaruhi penggunaan informasi sosial dan lingkungan. Trevino (1986) menjelaskan bahwa model pengambilan keputusan etis terdapat karakter lain yang mungkin berpengaruh seperti ego strenght dan field dependence. Selain faktor individu, faktor situasi mungkin juga 
mempengaruhi penggunaan informasi sosial dan lingkungan sebagaimana penelitian Hendricks (1976) dan Sarumpaet (2016). Selain itu, terdapat model yang dikembangkan oleh jones (1991) dan Trevino (1986).

Penelitian ini membuktikan bahwa daya prediksi teori stakeholder. Dalam konteks kepentingan yang dipertimbangkan, tidak hanya manajer dan pemilik sebagaimana dalam terori keagenan, penelitian ini juga membuktikan bukti empiris bahwa bagaimana manjer mengambil keputusan dalam kasus yang melibatkan pemangku kepentingan. Penelitian ini juga memberikan bukti empiris tentang bagaimana pihak internal menggunakan informasi sosial dan lingkungan yang selama ini hanya ada bukti empiris yang menunjukkan bahwa bagaimana pihak eksternal menggunakan informasi sosial dan lingkungan.

Implikasi dari penelitian ini adalah perlunya akuntan manajemen menyedikan informasi sosial dan lingkungan dalam pengambilan keputusan manajer. Seperti halnya yang telah diprediksi, ketika manajer mendapatkan informasi sosial dan lingkungan, manajer menjadikan informasi tersebut sebagai bahan pertimbangan dalam pengambilan keputusan. Selama ini, informasi sosial dan lingkungan belum terhubung dalam informasi yang disajikan akuntan manajemen sehingga sistem informasi manajemen yang baik saat ini belum efisien dan mengarahkan pada pengambilan keputusan yang buruk dan kurang akuntabel (Schaltegger, 2006).

Penyajian informasi sosial dan lingkungan akan memberikan dampak positif. Demski dan Feltham (1976) menjelaskan bahwa informasi sosial dan lingkungan mempengaruhi pengambilan keputusan dalam dua cara: secara langsung sebagai masukan atas keputusan dan secara tidak langsung mempengaruhi perilaku manajer. Hal ini akan menjadi sumber informasi sekaligus dapat merubah perilaku manajer sehingga bertanggungjawab sosial.

Segi pedekatan instrumental, hal ini akan meningkatkan kinerja keuangan perusahaan. Hal ini disebabkan oleh adanya pengaruh kinerja sosial perusahaan terhadap peningkatan kinerja ekonomi sebagaimana penelitian Surroca (2010) dan Simpson dan Kohers (2002). Oleh karena itu, penyajian informasi sosial dan lingkungan dapat mendorong peran akuntan dalam meningkatkan kinerja perusahaan. 
DAFTAR PUSTAKA

A Chariri dan Imam Ghozali. (2007). "Teori Akuntansi". Semarang: Badan Penerbit Universitas Diponegoro.

Ahmad, N.N.N., dan Sulaiman, M. (2004), "Environmental Disclosure Malaysian Annual Reports: A Legitimacy Theory Perspective", International Journal of Commerce and Management, 14,44.

Al-Tuwaijri, A.S., Christensen, T.E. and Hughes, K.E. (2004), "The relations among environmental disclosure, environmental performance, and economic performance: a simultaneous equations approach", Accounting, Organizations and Society, Vol. 29 No. 5-6, pp. 447471.

Anderson, J.C. and Frankle A.W. (1980), "Voluntary social reporting: an iso-beta portfolio analysis", The Accounting Review, Vol. 55 No. 3, pp. 467-479.

Anggraini, Fr. Reni Retno.(2006), "Pengungkapan Informasi Sosial dan Faktor-Faktor yang Mempengaruhi Pengungkapan Informasi Sosial dalam Laporan Keuangan Tahunan (Studi Empiris pada PerusahaanPerusahaan yang terdaftar Bursa Efek Jakarta)",Padang 23-26 September 2006, hlm 1-21.

Belkaoui, A. (1976), "The impact of the disclosure of the environmental effects of organizational behavior on the market", Financial Management, Vol. 5 No. 4, pp. 26-31.

Belkaoui, A.R. (2000).Teori Akuntansi.Edisi Pertama.Jakarta: Salemba Empat

Boddy, D. (2002), Managing Projects: Building and Leading the Team, Prentice Hall, London.
Clarkson, M.B.E. (1995), “ $A$ stakeholder framework for analyzing and evaluating corporate social performance", Academy of Management Review, Vol. 20, No. 1; pp. 92117.

Dari, Wulan (2015), Pengaruh Informasi Lingkungan dan Sosial Terhadap Keputusan Manajer (Studi Eksperimen di PT Hanjaya Mandala Sampoerna, tbk), Program magister jurusan akuntansi, Fakultas ekonomi dan bisnis, Universitas Gajah Mada Yogyakarta.

Donaldson, T. and Preston, L.E. (1995), "The stakeholder theory of the corporation: concepts, evidence, and implications", The Academy of Management Review, Vol. 20 No. 1, pp. 65-91.

Fisher, Cathy. 1996. The Impact of Perceived Environmental Uncertainty and Individual Differences on Management Information Requirements: A Research Note. Accounting, Organizatiom and Society. Vol. 21, No. 4, pp. 361-369.

Freeman, R.E. (1984), Strategic Management: A Stakeholder Approach, Pitman, Boston.

Freeman, R.E., Harrison, J.S., Wicks, A.C. Parmar, B. and de Colle, S. (2010), Stakeholder.

Freeman, R. Edward \& Robert A. Phillips. 2002. Stakeholder Theory: A Libertarian Defense. Business Ethics Quarterly. Vol. 12, No. 3 (Jul.), pp. 331-349.

Ghozali, I. 2006. Aplikasi Analisis Multivariate dengan Program SPSS. Edisi Empat. Badan Penerbit UNDIP. Semarang.

Grit, K. (2004), "Corporate citizenship: how to strengthen the social responsibility of managers", 
Journal of Business Ethics, Vol. 53 No. 1-2, pp. 97-106.

Guidry, R.P. and Patten D.M. (2010), "Market reactions to the firsttime issuance of corporate sustainability reports: evidence that quality matters", Sustainability Accounting, Management and Policy Journal, Vol. 1 No. 1, pp. 33-50.

Hall, M. (2010), "Accounting information and managerial work", Accounting Organizations and society, Vol. 35 NO. 3, pp. 301-315.

Harrison, P.D. and Harrell, A. (1993), "Impact of "adverse selection" on managers' project evaluation decisions", Academy of Management Journal, Vol. 3 No. 3, pp. 635-643.

Hassel, L., Nilsson, H. and Nyquist, S. (2005), "The value relevance of environmental performance", European Accounting Review, Vol. 14 No. 1, pp. 41-61.

Hendricks, J.A. (1976), "The impact of human resource accounting information on stock investment decisions: an empirical study", The Accounting Review, Vol. 51 No. 2, pp. 292-305.

Henri, J-F. and Journeault, M. (2010), "Eco-control: the influence of management control systems on environmental and economic performance", Accounting, Organizations and Society, Vol. 35 No. 1, pp. 63-80.

Henriques, I. and Sadorsky, P. (1999), "The relationship between environmental commitment and managerial perceptions of stakeholder importance", The Academy of Management Journal, Vol. 42, No. 1, pp. 8799.

Hill, C.W.L. and Jones, T.M. (1992), "Stakeholder-agency theory",
Journal of Management Studies, Vol. 29 No. 2, pp. 131-152.

Jensen, M.C. and Meckling, W.H. (1976), "Theory of the firm: managerial behavior, agency costs and ownership structure", Journal of Financial Economics, Vol. 3 No. 4, pp. 305-360.

Jones, T.M. (1995), "Instrumental stakeholder theory: a synthesis of ethics and economics", The Academy of Management Review, Vol. 20 No. 2, pp. 404437.

Jones, Thomas M. 1991. Ethical Decision Making by Individuals in Organizations: An IssueContingent Model. The Academy of Management Review, Vol. 16, No. 2 (Apr.), pp. 366-395.

Jones, T.M and Wicks, A.C. (1999), "Convergent stakeholder theory", The Academy of Management Review, Vol. 24, No. 2, pp. 206-221.

Kaya, Idil. (2016), "The mandatory social and environmental Reporting: evidence from France”, Procedia social and behavioral sciences 229 , pp. 206213.

KPMG (2013), "The KPMG Survey of Corporate Responsibility Reporting 2013”, availableat:http://www.kpmg.co m/Global/en/IssuesAndInsights/ ArticlesPublications/corporateresponsibility/Documents/corpor ate-responsibility-reportingsurvey-2013.pdf.

KPMG. (2015). Survey of Corporate Responsibility Reporting 2015, www.kpmg.com/crreporting.

KPMG. (2017). Survey of Corporate Responsibility Reporting 2017, www.kpmg.com/crreporting.

Larson, E.W. and Gray, C.F. (2011), Project Management: The 
Managerial Process, McGrawHill/Irwin, New York, NY.

Liyanarachchi, G.A. and Milne, M.J. (2005), "Comparing the investment decisions of accounting practitioners and students: an empirical study on the adequacy of student surrogates", Accounting Forum, Vol. 29, No. 2, pp. 121-135.

Madein, Mahfud Sholihin. (2015). The Impact of Social and Environmental Information on Managers' Decision. Asian review of accounting, Vol. 23 No. 2, pp. 156-169.

Mathews, M. R. (1997), "Twenty-five years of social and environmental research: is there a silver jubilee to celebrate?", Accounting, Auditing, and Accountability Journal, Vol. 10 No. 4, pp. 481-531.

Milne, M.J. and Patten, D.M. (2002), "Securing organizational legitimacy: an experimental decision case examining the impact of environmental disclosures", Accounting, Auditing, and Accountability Journal, Vol. 15 No. 3, pp. 372405.

Mulyadi. (2008). Akuntansi Manajemen : Konsep, Manfaat, dan Rekayasa. Jakarta : Salemba Empat.

Murray, A., Sinclair, D., Power, D. and Gray, R. (2006), "Do financial markets care about social and environmental disclosure?: Further evidence and exploration from the UK", Accounting, Auditing and Accountability Journal, Vol. 19 No. 2, pp. 228255.

Phillips, R., Freeman R.E. and Wicks, A.C. (2003), "What stakeholder theory is not", Business Ethics
Quarterly, Vol.13 No. 4, pp. 479502.

Rikhardsson, P. and Holm, C. (2008), "The effect of environmental information on investment allocation decisions - an experimental study", Business Strategy and the Environment, Vol. 17 No. 6, pp. 382-397.

Rutledge, R.W. and Karim, K.E. (1999), "The influence of self-interest and ethical considerations on managers' evaluation judgments", Accounting, Organizations and Society, Vol. 24 No. 2, pp. 173-184.

Sarumpaet, Susi. (2016), "The manager's decision in acknowledging and disclosing environmental liability: A behavior model", Journal of Economics, Business, And Accountancy Ventura, Vol. 19 No. 2, pp. 191-204.

Schaltegger, S., Bennett, M. and Burritt, R. (2006), "Corporate sustainability accounting, a catchphrase for compliant corporations or a business decision support for sustainability leaders?", in Schaltegger, S., Bennett, M. and Burritt, R. (Eds.), Sustainability Accounting and Reporting, Springer Publishing, Dordrecht, pp. 37-59.

Silver, D. (2012), “Citizens as contractualist stakeholders", Journal of Business Ethics, Vol. 109 No. 1, pp. 3-13.

Simpson, W.G. and Kohers, T. (2002), "The link between corporate social and financial performance: evidence from the banking industry", Journal of Business Ethics, Vol. 35 No. 2, pp. 97-109. 52

Sugiyono, 2015, Statistika Untuk Penelitian, Alfabeta bandung 
Surroca, J., Tribo, J.A. and Waddock, S. (2010), "Corporate responsibility and financial performance: the role of intangible resources", Strategic Management Journal, Vol. 31 No. 5, pp. 63-490.

Syamsi, Ibnu. (2000). "Pengambilan Keputusan Sistem Informasi”. Edisi ke-2. Cetakan kedua. Jakarta: Bumi Aksara.

Teoh, H.Y. and Shiu, G.Y. (1990), "Attitudes towards corporate social responsibility and perceived importance of social responsibility information characteristics in a decision context", Journal of Business Ethics, Vol. 9 No. 1, pp. 71-77.

Tiarasandy, Anita. (2018), "The Influence of Environmental Performence and Corporate Social Responbility Disclosure on Financial Performance (Empiric Studies on Companies Listed on PROPER in the Period of 2013-2015)", e-Proceeding of Management, Vol. 5 No. 1, pp 678-688.

Trevino, Linda K. 1986. Ethical Decision Making in Organizations: A PersonSituation Interactionist Model. The Academy of Management Review. Vol. 11, No. 3 (Jul.), pp. 601-61.

Vardon, Michael., Juan PC, Michael N, Sjoerd S. (2018), "How the system of environmentaleconomic accounting can improve environmental information systems and data quality for decision making", Environmental acince \& accounting, Vol. 89, pp. 83-92.

Wall, F. and Greiling, D. (2011), "Accounting information for managerial decision-making in shareholder management versus stakeholder management, Review of Managerial Science, Vol. 5 No. 2, pp. 91-135. 